This is the author's final, peer-reviewed manuscript as accepted for publication. The publisher-formatted version may be available through the publisher's web site or your institution's library.

\title{
Rural place attachment in Hispano urban centers
}

Jeffrey S. Smith

\section{How to cite this manuscript}

If you make reference to this version of the manuscript, use the following information:

Smith, J. S. (2002). Rural place attachment in Hispano urban centers. Retrieved from http://krex.ksu.edu

\section{Published Version Information}

Citation: Smith, J. S. (2002). Rural place attachment in Hispano urban centers. Geographical Review, 92(3), 432-451.

Copyright: Copyright $\odot 2003$ by the American Geographical Society of New York

Digital Object Identifier (DOI): doi:10.1111/j.1931-0846.2002.tb00152.x

Publisher's Link: http://onlinelibrary.wiley.com/doi/10.1111/j.1931-

0846.2002.tb00152.x/abstract

This item was retrieved from the K-State Research Exchange (K-REx), the institutional repository of Kansas State University. K-REx is available at http://krex.ksu.edu 


\title{
Rural Place Attachment in Hispano Urban Centers
}

\author{
Geographical Review
}

\author{
Jeffrey S. Smith \\ Department of Geography \\ 118 Seaton Hall \\ Kansas State University \\ Manhattan, KS 66506-2904 \\ Phone: (785) 532-3412 \\ Fax: (785) 532-7310 \\ jssmith7@ksu.edu
}

For a complete pdf version of this article visit: www.k-state.edu/geography/JSSmith/

* I gratefully acknowledge Kevin Blake's assistance on earlier drafts of this article.

Dr. Smith is an assistant professor of geography at Kansas State University, Manhattan, Kansas 66506-2904 


\section{Rural Place Attachment in Hispano Urban Centers Jeffrey S. Smith}

ABSTRACT. Continued rural to urban migration is helping to motivate cultural geographers to better understand the complexity of the urban structure. Interpreting patterns of gender, class, ethnicity, and commercialization have proven to be fertile research areas, yet little is understood of the links between rural and urban places. Despite intense feelings of loyalty to their rural villages, the 1940s witnessed Hispanos moving en masse to cities. By the 1950s, due to higher wages and secure employment, a majority were living in regional urban centers. The Hispano experience provides a valuable crucible to examine how the attachment urbanites have for rural places is manifested in various urban cultural expressions. Presenting examples garnered from the cities of Albuquerque, Española, and Santa Fe, New Mexico and Pueblo, Colorado, this article illustrates how painted murals, burial preferences, popular music, and irrigation ditches provide urban dwellers with a link to the rural village ideal. Understanding threads of rural culture that have been incorporated into the urban fabric leads to a clearer comprehension of the emotional attachment urbanites have for rural areas and a better appreciation of the complexity of the urban cultural environment. Keywords: rural villages, urban place attachment, Hispanos, New Mexico, Colorado.

Since the end of the Second World War, American cities have been attracting greater numbers of new residents seeking diverse employment opportunities and amenity-rich environments ${ }^{1}$. Over the past two decades, Atlanta, Denver, Houston, Las Vegas, and 
Phoenix have consistently topped the list of the fastest growing urban centers in the U.S. With surrounding lands being gobbled up at over an acre an hour, rapid urbanization is coming at a heavy environmental and social price (Stoel 1999). As recent news headlines indicate, for many people cities have become a stress-inducing, inhospitable and impersonal environment (Muir 1999) with polluted air, rampant road rage, heinous hate crimes, and traffic congestion. Cities are popularly perceived as the root of many social ills. Conversely, rural areas are more commonly regarded as warm and friendly places where one can escape the urban jungle to find peace, solace, and comfort (de Wit 1997; Jakle 1999). As sanctuaries possessing restorative powers, rural places have become an idyllic retreat from the "increasingly urbanized and fast-paced world beyond" (Wyckoff and Dilsaver 1995, 4).

One way urbanites deal with the 'evils' of living in urban centers is by incorporating non-urban aspects into their daily lives. While the romanticized 'country' living centers on finding the serenity of nature, rural small town places offer a nurturing extended family atmosphere where residents personalize their relationships and forge strong ties to place (Jakle 1999). Living in a city can be more tolerable when one is surrounded by reminders of the more peaceful, caring, wholesome virtues of a rural lifestyle (Little 1999). Working to further our understanding of the complexity of the urban structure, the purpose of this article is to illustrate how urban-dwelling residents have incorporated aspects of the rural village ideal into their city lives. The approach I take in improving our understanding of the link between rural and urban places is to explore rural place attachment among urban-dwelling Hispanos ${ }^{2}$. My analysis focuses 
on the attachment residents of Albuquerque, Española, and Santa Fe, New Mexico, and Pueblo, Colorado have to rural places.

\section{LANDSCAPE ANALYSIS MOVES TO THE CITY}

American cultural geographers have long been recognized for their meticulous examination of the built environment (Wagner and Mikesell 1962; Norton 1989; Foote et al. 1994; Myers et al. forthcoming 2002). For decades geographers with a cultural focus have also interpreted patterns of ordinary cultural landscapes (Meinig 1979a; Groth and Bressi 1997) including the work of such well-known scholars as Peirce Lewis (1979), Donald Meinig (1979b), 'J.B.' Jackson (1984, 1994), Allen Noble (1992), Wilbur Zelinsky (1992), and Terry Jordan, Jon Kilpinen, and Charles Gritzner (1997). A majority of these 'traditional' pieces have focused on the attributes of rural, folk, and pre-industrial societies. As James Duncan (1990) and others have acknowledged, the methodologies and corpus of knowledge advanced by this approach to cultural geography research has provided a solid foundation and tested set of axioms upon which the future of the subdiscipline can be built.

Increasing urbanization, however, combined with a call for the application of more socially grounded and theoretically based investigation (Cosgrove and Daniels 1988; Jackson 1989; Cosgrove 1993, 1994; Duncan 1994; Mitchell 1994; Duncan and Ley 1997; Holdsworth 1997), is precipitating a shift in the research agenda of today's, largely 'new', cultural geographers. Social interaction within urban and industrial places 
(Ley 1996; Hayden 1997; Wheeler 1998; Peach 2002) is helping drive the research of today's cultural geographers. Furthermore, the 1990s witnessed a growing number of scholars exploring the complexity of urban centers (Muir 1999; Myers et al. forthcoming 2002), especially those trying to understand how landscapes play an active role in the development of culture (Mitchell 1994; Wheeler 1998). Interpreting urban patterns of ethnicity (Arreola 1994; Ruddick 1996; Wood 1997; Li 1998), gender relations (Hayden 1981; Watson 1988; Spain 1992; Jacobs and Fincher 1998), employment and class (Blake and Arreola 1996; Mitchell 1997; Bondi 1998; Hiebert 1999), social and political economy (Harvey 1989; Zukin 1995; Mitchell 1996; Warren 1996; Kloosterman et al 1999) and development, consumption, and commercialization (Kenny 1995; Smith 1996) are proving to be particularly fertile areas of research. Of growing interest, especially among the postmodern and poststructuralist geographers, is the analysis of social-spatial contestations in urban settings (Mills 1997). The amalgamation of contemporary cultural geography studies is affirming that values, ideologies, and identity are all meaningfully represented in the socially constructed landscape. Unfortunately, as the laments of a chorus of scholars indicate (Parsons 1994; Wheeler 1998; Mitchell 1999), we have done little more than scratch the surface in our attempt to comprehend the complexity of urban culture.

As increasing numbers of cultural geographers reposition their research endeavors and move from an examination of rural locations to cities, a gap is being left in the body of literature. The ongoing blurring of rural and urban culture (Rigg 1998) requires more work be done at their interface so we can more fully appreciate the link 
between rural and urban places. Urban Geography editor James Wheeler (1998) issued a call for manuscripts that focus on the interconnections between rural and urban places. His words reflect the growing realization that only through such scholarly endeavors will we improve our understanding of how urban cultural landscapes are constructed. "A more substantive understanding of landscape ... cannot focus on the country or on the city, but must incorporate the mutual definition and relations of both" (Olwig 1996, 645). The discord between 'traditional' (largely rural) and 'new' (predominantly urban) cultural geographical approaches only serves to limit scholars' scope of research. An effective way of decoding the hidden meanings within the complexity of urban centers is to more closely examine the various interlinkages between rural and urban places. "As a cultural construct, the meaning of the city can be deciphered by closely examining its complex relationship with the culture of which it is a part" (Domosh 1992, 475). A clearer appreciation of links between rural and urban culture will better inform us about the urban experience.

\section{PLACE ATTACHMENT}

By the late 1970s cultural geographers had devoted relatively little research energy to understanding how people's knowledge of place is organized or the emotional feelings people have for places (Wright 1947; Tuan 1977; Sopher 1979). In an attempt to help rectify this shortcoming in the literature, Yi-Fu Tuan published two treatises that explored people's emotional attachment to place. He first introduced the concept of 
Geopiety (Tuan 1976) -- the intersection of people's pious devotion to place with one's land or country. This contribution helped readers begin to grasp the idea of reverence for home. In Space and Place (1977) Tuan explained the concept of a homeland as "an archive of fond memories and splendid achievements that inspire the present; place is permanent and hence reassuring to man" and "the more ties there are [to a place], the stronger is the emotional bond" (Tuan 1977, 154 and 158).

Both of Tuan's early works broke ground on research devoted to understanding how people's deep emotional attachment to place develops. Since that time, however, there has been intermittent interest among cultural geographers in the strong attachment people have for a place. Ben Marsh's (1987) acclaimed work on anthracite mining towns in northeastern Pennsylvania is one such example. Marsh explains that, despite endemic poverty and economic collapse, residents refused to leave their home communities because of their unconditional bonds with the place and sense of rootedness.

The body of geographical literature on emotional attachment to place advanced considerably in the early 1990s. Following the monographs of Alvar Carlson (1990) and Richard Nostrand (1992), and a session at the 1991 meeting of the Association of American Geographers in Miami, Florida, a special issue of the Journal of Cultural Geography was devoted to advancing understanding of the homeland concept. Guest editors Richard Nostrand and Lawrence Estaville, Jr. (1993) solicited ten scholars to persuasively argue for the emerging concept and demonstrate how their research is an example. While it was agreed that some culture groups bond with a place more readily 
than others, consensus among the contributing authors indicates that the most important ingredient needed for the development of a homeland is deep emotional attachment to a place (Arreola 1993; Boswell 1993; Conzen 1993; Jordan 1993; Nostrand and Estaville, Jr. 1993; Roark 1993).

The homeland concept is significantly improving our appreciation of the deepseated feelings people have for a place. While Nostrand and Estaville's (2002) anthology adds to the literature on the homeland concept, more geographical accounts are needed to enrich that understanding of place attachment. As Richard Muir concludes, "[o]ften the significance of place and the meanings associated with [that place] lie at the core of a person's identity", yet "much concerning the relationship between people and places remains poorly understood" $(1999,274)$.

Dolores Hayden has recognized that scholars from various cognate fields are also examining place attachment. "[E]nvironmental psychologists ...define place attachment as a psychological process ....and suggest that place attachment can develop social, material and ideological dimensions, as individuals create ties to kin and neighbors, ...and participate in public life as residents of a particular community" (Hayden 1997, 112). Place attachment has also been incorporated into the research agenda of many sociologists as they try to explain the power of human connections to place that may no longer exist (e.g. neighborhoods lost to urban renewal) (Hayden 1997). Some scholars have even argued that there should be more research on the need to belong to a particular place from a biologically based research perspective as it incorporates the concept of territoriality (Muir 1999). 
Cultural geographers obviously have no monopoly on the study of place attachment, but they should be capitalizing on their unique perspective of landscape analysis to further understand the deep-seated ties people have for particular places. “When [people's] experience of other places suggests that some familiar things at home may be distinctive, these become symbols of home" [emphasis added] (Sopher 1979, 137). Cultural geographers are best qualified to read the 'symbols of home', especially as they are manifested in ordinary landscapes. Few geographical studies have provided evidence of the extent to which urban residents bond with rural places. More geographers need to analyze the urban landscape for the strong emotional attachment city dwellers have for rural areas. Using the Hispano urban experience, this study reveals some of the symbols of the interplay between rural and urban places which in turn should further our comprehension of the complexity of the urban structure.

\section{HISPANOS OF THE UPPER RIO GRANDE}

Early New Mexico scholars quickly concluded that for Hispanos the community in which they were born and raised is most meaningful in their life. In 1954 John Burma wrote that it is impossible to overemphasize the importance of the home village to Hispanos (Burma 1954). He stressed that individuals are identified first and foremost with their community of birth, and loyalty to the community reaches a degree unknown in most of the United States. Little has changed over the past four and one-half decades. The home community is still central to the lives of Hispanos (Martin 2000). 
As Richard Nostrand concluded in 1992, no other place is as meaningful to them as their Patria Chica (native village). Two popular New Mexico publications have further captured the essence of this. The September 1997 issue of New Mexico Magazine featured an article on La Querencia (the place of your heart's desire) (Fauntleroy 1997). For Hispanos, their querencia is the village in which they were born and raised -- the place they feel completely at home and know they belong. The other publication, $\mathrm{La}$ Herencia del Norte, has periodically featured letters to the editor under the subtitle "Hogar dulce Hogar" (loosely translated to mean: Home Sweet Home). Contributors explain what makes living in their New Mexico village meaningful and special to them. Because of the unequaled bonds they have for their rural villages of northern New Mexico and southern Colorado, Hispanos make an ideal culture group for examining the ties urban residents have for rural places.

Prior to the 1940s, Hispanos were principally subsistence farmers and ranchers. As documented by Sarah Deutsch (1987), while numerous Hispano men took jobs as itinerant laborers in the potato and sugar beet industries of northern and central Colorado, they always returned home to their small village. In the 1940s, however, despite their deep attachment to home, Hispano families began moving to regional urban centers that offered higher paying jobs largely unavailable in the communities of their birth. By the middle of the 1950s a majority of all Hispanos were living in the urbanized areas of Albuquerque, Denver, Pueblo, Española, Santa Fe, and Phoenix (Nostrand 1992). Because of the deep emotional feelings Hispanos have for the villages of their family's roots, many former residents continue to own property returning 
on weekends, holidays, and vacations (Carlson 1990; Smith 1997; Martin 2000). Furthermore, aspects of their lives that remind them of the rural village ideal have become particularly meaningful. How have Hispanos incorporated their extraordinarily deep emotional attachment for rural areas into their city lives?

In pursuing an answer to this question, evidence was amassed from over seven years of personal fieldwork and informal interviews throughout the rural villages and urban centers of New Mexico and southern Colorado. During the summers of 1998 and 1999 and the fall of 2000, energy was devoted to a systematic analysis of the landscape in the New Mexico cities of Albuquerque, Española, and Santa Fe as well as Pueblo, Colorado (Figure 1). In addition to commercial districts, my field observations of public space (places where the landscape has been influenced by a community of people) focused on residential zip code areas with, according to the 1990 U.S. Census, a plurality of Hispanos ${ }^{3}$. The veracity of my personal observations were verified through numerous informal interviews with key informants including housewives, retired couples, employed and unemployed/disabled residents, business owners and directors, business employees (both male and female), scholars from local colleges/universities, and government officials. Extensive daily notes, photographs, and sketches were taken to document my findings and allow synthesis and distillation of the information. The strong ties urban-dwelling Hispanos have for rural areas run deep as evidenced by murals, mortuaries, music, and acequias (irrigation ditches).

MURALS 
From the preservation of historic buildings to the creation and designation of public landmarks and memorials, people mark their heritage in a variety of ways. Highly visible features, such as Mt. Rushmore or the Washington, D.C. monuments, hold public significance and serve to enhance people's sense of place (Tuan 1977). On a less grandiose scale, ethnic groups personalize their landscape to help establish the character of the place as well as maintain community identity (Ford and Griffin 1981). Features on the landscape thus serve to consolidate shared meanings and act as community builders (Duncan and Ley 1997).

The creation of public murals is a common method of enhancing community identity among Hispanic populations. These expressions of vernacular art promote community pride, cooperation, and stability (Ford and Griffin 1981) while simultaneously signaling the presence of a particular ethnic substrate within the larger urban center (Hayden 1997). After an extensive examination of murals in San Antonio, Texas, Daniel Arreola (1984) concluded that painted murals are a visual landscape artifact that supplements oral tradition. "[B]y re-creating and projecting images of well-known ...personalities as well as historic events ...murals serve as mnemonic devices" (Arreola 1984, 414-17). As Arreola explains, in the absence of written records, murals adorning public space are an enculturating medium that strengthen group memory.

For Hispanos of the upper Rio Grande region public murals have long been a popular form of cultural expression among rural-dwelling residents. Many rural Hispano communities contain artistic renditions that dress the landscape of both private 
dwellings and public space. Evidence presented here suggests that similar idealized scenes now appear in urban centers with a large Hispano population.

In San Luis, Colorado, for example, well-known regional artist and sculptor Carlos Sandoval painted a mural that graces a wall in the heart of the rural community (Figure 2). The mural depicts the region's cultural traditions, life in the rural Hispano community, and the bountiful goodness of the earth. Crowning the top of the mural are four Spanish conquistadors in full armor and the crucified Christ. This section of the mural is particularly laden with cultural meaning, not only for religious significance, but because the conquistadors signify the important distinction Hispanos make between themselves and all other people of Hispanic origin in the United States. Equally impressive is the mural in rural Truchas, New Mexico (Figures 3) that carries viewers from the top of the Sangre de Cristo Mountains, down the valley to the religious mecca of Chimayó, New Mexico. Imbedded in the rural scene are locally prominent physical and cultural features. Finally, a mural in San Miguel, New Mexico honors the local Catholic Church and the important role it has played in the lives of the resident population (Figure 4). The mural recounts major figures and events in the life of the church and the community. For the rural-dwelling Hispanos who live in communities such as these, the murals consolidate shared meanings by reminding them of the richness of their lives and their cultural traditions.

In the Atrisco suburb on Albuquerque's west side, murals serve a similar purpose. A common mural theme is the rural village ideal. In one section of the Atrisco suburb residents of the Alamosa neighborhood were having a particularly difficult time 
fighting gang activity and graffiti. One resident (preferring to remain anonymous) explained that the community responded by bonding together to promote a cleaner, safer environment. Even more significant, however, children and adults within the neighborhood painted murals on perimeter walls depicting positive aspects of their lives around which other members of the community could rally. While many of the murals have a religious connotation, of noteworthy importance is the panel that depicts a small village at the base of what is unquestionably the Sangre de Cristos -- the principal mountain chain of New Mexico and southern Colorado along the Rio Grande (Figure 5). The home village has thus become an ideal brought to the city in which residents can find comfort and security.

Another mural found in the Atrisco suburb features a similar bucolic scene painted on the walls of the forlorn looking Santa Clara Cemetery. Completed in 1999 by Leopoldo Romero, the mural depicts an idealized view of a small town with two prominent churches and adjoining cemeteries (Figure 6). The idealized scene helps reconnect with a lost or distant past and suggests that eternal peace and happiness are only achieved when one's final resting place is among the rural hills of home. Equally telling is that by the fall of 2000 some sections of the mural had been scaled off and graffiti added. Yet, the idealized rural scene has been left unblemished.

\section{MORTUARIES}

For some Hispanos, being buried behind a cemetery wall that looks similar to the 
small village of their birth is simply not good enough; their desire is to be buried in the town of their family's roots.

One of the greatest challenges in identifying ties between rural communities and urban centers is overcoming the fact that most of the links tend to be very personal and therefore nearly invisible to public scrutiny. Such is the case with burial practices of deceased family members. As cultural spores, cemeteries are a landscape artifact housing a wealth of information. Physical anthropologists have long known that burial grounds are an indispensable tool in uncovering the secrets of a local culture. Unfortunately, however, cemeteries reveal little about the last known place of residence of the deceased; such information goes largely unreported on cemetery headstones.

Graham Rowles and Malcolm Comeaux (1987) assert that post-death migration (the long distance removal of human remains) is strongly correlated to people's attachment to place. They provide evidence showing that, cross-culturally, people desire to be laid to rest in a place for which they hold a particular affinity. Often that place is called their 'home'. For some, home is their place of birth; for others home is a place where significant events unfolded during the person's lifetime. For most Hispanos their home is unquestionably the village of their family's roots. With few alternatives available, data from interviews with mortuary directors were used to track the final journey after the end of a person's lifetime.

In the commercial districts of the cities I examined, numerous mortuaries serve the local population's needs. The funeral homes, however, tend to be commercially segregated based on ethnicity. In Española, for example, the Block-Salazar Mortuary 
provides most of the burial services for the local Hispanic population. According to monument consultant Alicia Duran (1999), slightly more than $20 \%$ of their business relates to deceased who want to be interred in their hometown cemetery. In these situations, Block-Salazar Mortuary typically conducts two services; one at the mortuary for family and friends who live in the Española / Santa Fe area, and a second grave side service in the small town cemetery. Duran explained that most of their out-of-town business is in the small villages of northern New Mexico and southern Colorado.

In Pueblo, Colorado, of the twelve mortuaries offering burial services, the Romero Family Funeral Home is the recognized leader serving the local Hispanic population. Director Larry Romero (1999) informed me that nearly $15 \%$ of the services conducted at his mortuary are for families whose relative desired to be buried in their hometown cemetery. For the Romero Family Funeral Home, the majority of their nonlocal burials serve Hispanos who lived in Colorado's San Luis Valley -- a rural Hispano stronghold (Smith 1999).

FOLK MUSIC

From highbrow classical to the pulsing rhythm of rap and bebop, music is one of the purest forms of cultural expression. Music plays an integral part in expressing tastes, preferences, fears, and fantasies. It also serves as an effective means by which memories of a place are recalled. Over the past three decades a growing number of cultural geographers have interpreted the geography of music. As illustrated by the 
carefully composed overviews of Lily Kong (1995), and Peter Nash and George Carney (1996), as well as the special 1998 music issue of the Journal of Cultural Geography (Carney 1998), music research has become extensive and varied. One of the more popular themes has been the interpretation of place identity in music (Carney 1990), yet most of this research has focused on either rock and roll or country music (Carney 1998; Curtis and Rose 1983; Kong 1995). For example, Louis Woods' and Charles Gritzner's (1990) content analysis of country music concludes that a portion of the genre portrays a nostalgia and yearning for a simpler way of life. People's disenchantment with urban living, especially among uprooted migrants, leads to a homesickness for the rural landscape and agrarian lifestyle. They conclude that country music is a symbolic reminder and expression of desire for a past time and distant place.

For many ethnic groups music is a vital source of subcultural identity. Unfortunately, place-specific analysis employing ethnic music has been largely ignored by geographers (Curtis and Rose 1983). As George Carney laments, "[our] geographic knowledge of ethnic music is practically nil despite the fact that anthropologists, folklorists, and ethnomusicologists have for years studied variations in both rural and urban contexts." He wonders "[W]here are the geographical studies on the rich and variegated music traditions of the Hispanic Southwest, French of southern Louisiana...?" (Carney 1998, 5). Still more surprising is that geographers have all but overlooked how ethnic music perpetuates social identity, strengthens a group's perception of space, and helps maintain cultural or ethnic ties to a place (Kong 1995).

In traditional rural Hispano communities, music accompanies a large part of 
village life. From the melodious hymns of church, and alabados (ballads) sung during holidays and family celebrations to the Penitente chants, music adds flavor to Hispano culture. It is at community celebrations, however, where music strikes a special chord. According to local author Nasario Garcia (1999), the feast day celebrations with its music and dancing are especially important events in the life of the rural Hispano community. Historically each village typically supported three or four musical groups that played at these special social events. Some of the more talented groups gained a regional reputation and were paid to travel to nearby villages to play. Today the tradition of small bands and musical groups in rural Hispano villages continues.

Described as a blend between Spanish guitar and German polka music, Hispano songs have a clarity and heart-felt tone that distinguishes them from other LatinAmerican music, including Tejano music (Welsh, Jr. 1999). The more defining characteristic of Hispano music however, is that most songs tend to be corrido (musical folk tales) in nature. Many Hispano corridos can be traced to medieval Andalusia verses and ballads brought over by colonial Spaniards (Herrera-Sobek 1993). Corridos have always been a traditional Hispano way of expressing feelings through song and an important way of disseminating newsworthy information (Lopez 1999; Chavez-Bent 2000). Today, some of the most popular Hispano corridos are tales about life in rural New Mexican villages.

When famous Hispanic songwriter Micky Cruz left New York City after high school, he started his career by playing for audiences throughout New Mexico. Before he played for Bo-Diddley or founded 'Cruzin Records', Micky recounts that Hispano 
audiences asked him to quit playing those other songs and play the traditional songs everyone loves (Lopez 1999). "So [he] went to a record store and bought some tapes to learn traditional songs from New Mexico so [he] could keep his job" (Lopez 1999, 45).

Today urban-dwelling Hispanos continue to yearn for those traditional corridos that are rooted in the rural areas. As one of over 60 radio stations in the Albuquerque and Santa Fe listening area, Public Radio station KANW, has helped meet that demand with its New Mexico Spanish Music format. The station plays songs representative of the music traditionally found in the villages of northern New Mexico. According to Program Director George Welsh, Jr. (1999), all of the Hispano music aired on KANW has been written and performed by local New Mexico artists only. The station's policy is that any recording sent in will be played on the air at least once -- no matter the talent level. Welsh, Jr. indicates that many of today's older New Mexico residents enjoy singing, playing, and listening to the traditional songs they heard their parents and grandparents sing as they were growing up.

After introducing its current format in 1973, the station has enjoyed tremendous success. Inter-mixed with news and personal dedications, the time slot between 5:00am and 3:00pm each Saturday is the overall number one rated slot in the entire listening area; no other time slot captures a larger share of listeners in the Albuquerque and Santa Fe metropolitan areas (Welsh, Jr. 1999). Like other Public Radio Stations, KANW conducts semi-annual fund-raising campaigns. Due to the station's overwhelming popularity however, they have been able to scale back their semi-annual fund raisers, supplementing them with a single campaign held one Saturday each year. 
In eight hours the station is able to raise more money than it does during the other two campaigns combined (Welsh, Jr. 1999).

Another source of revenue for the station has come from selling cassette tapes and compact discs of the more popular New Mexico Spanish songs. Filled with 16 songs, volume one sold over 10,000 copies between 1997 and 1999. In 1998 volume two was released and as of the summer of 1999 had sold well over 8,000 copies. A wide variety of songs make the cut, but those about local New Mexico villages are some of the most popular. For example, Paul Piño sings about "Las Estrellias de Nuevo Mexico", Steve Ortiz has a song titled "Que Viva New Mexico" and one of Roberto Griego's most recognized songs is "Arriba Nuevo Mexico". These artists' popularity is due in large part to the fact that they sing about small New Mexico towns people are intimately familiar with. Welsh, Jr. (1999) says people simply can't hear these songs enough; they are constantly calling in to request them.

In an attempt to further capitalize on the appeal listeners have for the Hispano small towns, in 1998 KANW erected a relay tower in the far northern New Mexico village of Questa. Located over 150 miles north of Albuquerque, Questa's 1990 population was about 1,700 people. By adding to its extensive network of relay towers, KANW is able to effectively link rural and urban dwelling residents throughout the northern part of the state. More importantly, however, each year during Questa's feast day celebration KANW airs a 'live remote' from the town. All of the day's events are broadcast to the urban listening audience. Through the live remote Hispanos who live in two of the state's largest cities are able to maintain ties to the rural village ideal. 


\section{ACEQUIAS}

In the harsh, semiarid climate of the American Southwest few things are more important to the survival of a community than a dependable supply of water. Colonial Spaniards quickly recognized that ditch irrigation is one of the most effective means of diverting spring snowmelt and summer rains to croplands. Taking years to complete, construction of community acequias [ah-SAY-key-ahs] (irrigation ditches) began immediately after settlements were established. Once completed, acequias and their lateral ditches require year-round maintenance. For generations acequias have served as a veritable lifeline to rural Hispano villages, permitting residents to cling tenaciously to an otherwise hostile environment. The time-tested practices of Spanish forefathers have been used for centuries; crops are watered today using the same acequias.

While the seasonal rhythm of ditch irrigation with its repeating cycles of planting and harvesting seldom directly bear on the lives of urban dwelling Hispanos, the importance of rural acequias has not been forgotten. In the cities of Española and Santa Fe for example, local populations have commissioned works of art to help remind them of the vital role acequias have played in Hispano culture.

On the campus of Northern New Mexico Community College in Española, a monument entitled Monumento de Acequias has been erected and dedicated to acequias for the significance they hold to traditional Hispano culture. Etched in the sides of the work are words and phrases that remind visitors of the importance of 
acequias to the region's cultural heritage. Even more significant is the fact that the monument is flanked by the main irrigation ditch that historically delivered water to rural croplands in the same valley that now holds present-day Española. The monument not only provides a link between the rural past and the urban present, it also provides a focal point to a bucolic scene on the grounds of an active urban college campus.

In Santa Fe, New Mexico two other public works of art skillfully capture the sentiment urban dwellers have for acequias. Roughly six blocks southeast of the New Mexico State Capitol building is the city's old acequia madre (main/mother ditch). As noted by the abundantly placed state historical markers, the ditch was constructed at the time of the first Spanish settlement in the area. Today, both the elite, upper-income neighborhood and narrow, adjoining street derive their name from the ditch. It has been numerous decades since the ditch carried water to croplands, but the meaning of the ditch to the local residents has not faded. Gracing the west-facing wall of the Acequia Madre Elementary School is a captivating mural completed in 1989 by famous local artist Frederico Vigil with funding from the City of Santa Fe Arts Commission (Figure 7). A careful examination reveals that the scene joyfully depicts a celebration of everyday rural life along an acequia with water filled with fish and baskets full of crops waiting to be harvested. According to an adjacent plaque the mural is "[D]edicated to the acequia madre mayordomos [ditchbosses]. May the mother ditch continue to flow and give life to all future generations." For residents who live in the area and send their children to the school, the mural and the acequia madre are a connection to the rural cultural roots of the region. 
In the governmental heart of New Mexico lies a final example of the link between rural and urban places in Hispano cities. One of the newest displays in the State Capitol Annex is a sculpture entitled "Acequia" (Figure 8). As one of 25 invited entries, Tim Hooton's winning sculpture was selected by the Capital Arts Foundation because it most skillfully captured the essence of New Mexico culture (Larese 2000). The five foot by seven foot half sculpture, half fountain is a stylized depiction of a man opening an acequia head gate allowing water to flow over a mud-cracked, parched earth. The project was commissioned by the Arts in Public Places Program of the New Mexico Legislature as part of their effort to capture the contemporary cultural character of the state. Tim Hooton is quoted as saying "I went with the acequia concept because it is so symbolic of the complex and varied culture in New Mexico" (Larese 2000, 19). Viewers of the sculpture are instantly reminded of the importance of water in the development of the state and the interconnections between rural and urban places (Larese 2000).

\section{CONCLUSION}

Until now the links between rural and urban places have been largely ignored by cultural geographers. The bifurcated nature of research within cultural geography (i.e. 'traditional' rural vs 'new' urban) (Peach 2002) has left a gap in our comprehension of the urban structure. Only through synthesis will we improve our appreciation of the cultural environment in which an ever increasing proportion of the world's population is living. 
This article has used the Hispano urban experience as a window through which the ties between rural and urban places can be examined. The Hispano culture is ideally suited for this type of analysis because of the extraordinary deep feelings of attachment Hispanos have for the village of their family's roots. Empirical evidence shows that murals painted on neighborhood walls depicting the rural village ideal, the preference to be buried in one's hometown cemetery, rural-based place specific music that fills the air waves, and public art that celebrates the shared vision of the importance of rural acequias all speak of the strong ties Hispanos have for the small villages of the upper Rio Grande. Each of the aspects highlighted here boldly remind urban-dwelling Hispanos of their cultural roots, thereby reinforcing their cultural identity and in turn giving them feelings of comfort, security, and belongingness.

By explaining how the rural village ideal has been incorporated into cities, this paper has helped improve our understanding of the complexity of the urban experience. Additionally, my informal interviews with mortuary directors has introduced a new and previously untapped data source for studies of migration, interconnections of places, and patterns of place attachment. My focus has been on the Hispano culture, yet as more geographers analyze other culture groups for the attachment urban residents have for rural places, our appreciation of the cultural institutions that help create the complexity of the urban structure will increase.

1. One of the major exceptions to this predominantly rural to urban migration trend was 
the 'migration turnaround' of the 1970s.

2. As a number of scholars have convincingly documented (Burma 1970; Campa 1979; Jones 1979; Carlson 1990; Nostrand 1992), due to early isolation (from colonial settlement to circa 1860s), Hispanic residents of northern New Mexico and southern Colorado consider themselves distinct from all other Hispanic-Americans. They claim, vehemently at times, to be direct descendants from the original Spanish settlers and have developed unique cultural traditions. Therefore, most of the resident Hispanic population refers to themselves interchangeably as Spanish-Americans or Hispanos. I have chosen to use the latter moniker in this paper.

3. All four of the cities examined have a sizable Hispano population. Hispanos comprise the largest percentage of the resident population within the southwest quadrant of the Duke City metropolitan area, an area known vernacularly as the Atrisco suburb. Due to widespread Anglo intrusion and subsequent Hispano displacement throughout most of Santa Fe, my research focused on the southern edge of the capital city where a sizeable Hispano population remains. I also examined the landscape in the central (therefore oldest) section of the city near the plaza and capitol building. In Española, Hispanos are evenly distributed and dominant throughout most of the city, therefore, my fieldwork was not restricted to any one particular city sector. The Hispano population of Pueblo, Colorado is concentrated in four major sections. My focus was on the areas 
known locally as "Hyde Park" and "The Bessemer District" on the northwest and southwest sides of the city, respectively. 